\title{
PENGEMBANGAN WEBSITE EDUCANDY SEBAGAI ALAT EVALUASI PADA PEMBELAJARAN BAHASA INDONESIA UNTUK SISWA KELAS V
}

\author{
Prabawati Nurhabibah, Fikriyah, Komala Dewi \\ Pendidikan Guru Sekolah Dasar, Fakultas Keguruan dan Ilmu Pendidikan, Universitas \\ Muhammadiyah Cirebon, Jalan Tuparev No.70 Cirebon Jawa Barat Indonesia \\ prabawati@umc.ac.id
}

\begin{abstract}
ABSTRAK: Penelitian ini bertujuan untuk mengetahui (1) langkah-langkah pengembangan evaluasi pembelajaran interaktif berbasis Website Educandy, (2) kelayakan dari pengembangkan evaluasi pembelajaran interaktif berbasis Website Educandy. Model pengembangan yang digunakan dalam penelitian ini adalah model penelitian dan pengembangan Thiagarajan, juga dikenal sebagai model pengembangan 4-D. Tahap definisi, tahap desain, tahap pengembangan, dan tahap diseminasi adalah empat tahap Produk yang telah dikembangkan secara efektif sebagai hasil dari penelitian ini. Penelitian ini menghasilkan produk evaluasi pembelajaran interaktif untuk pembelajaran bahasa di Kelas V. Berdasarkan uji kelayakannya oleh ahli media dan materi, validasi kelayakan dari validator ahli media diperoleh persentase validitas sebesar 86,67 persen, sedangkan kriteria sangat layak termasuk dalam hasil validasi kelayakan dari ahli materi I yang diperoleh persentase validitas sebesar 93,33 persen, dan kriteria sangat layak termasuk dalam hasil validasi kelayakan ahli materi II diperoleh persentase validitas sebesar 93,33 persen.
\end{abstract}

KATA KUNCI: Evaluasi Pembelajaran Interaktif, Website Educandy

\section{DEVELOPMENT OF THE EDUCANDY WEBSITE AS A TOOL OF EVALUATION IN INDONESIAN LEARNING FOR CLASS V STUDENTS}

ABSTRACT: This study aims to determine (1) the steps for developing an interactive learning evaluation based on the Educandy Website, (2) the feasibility of developing an interactive learning evaluation based on the Educandy Website. The development model used in this study is the Thiagarajan research and development model, also known as the 4-D development model. The definition stage, the design stage, the development stage, and the dissemination stage are the four product stages that have been developed effectively as a result of this research. This study resulted in an interactive learning evaluation product for language learning in Class V. Based on the feasibility test by media and materials experts, the validation of the feasibility of the media expert validator obtained a validity percentage of 86.67 percent, while the very feasible criteria were included in the feasibility validation results from the material expert. I obtained a validity percentage of 93.33 percent, and very feasible criteria included in the results of the validation of the feasibility of material experts II obtained a validity percentage of 93.33 percent.

KEYWORDS: Interactive Learning Evaluation, Educandy Website

\begin{tabular}{|c|c|c|c|}
\hline $\begin{array}{l}\text { Diterima: } \\
\text { 2021-08-31 }\end{array}$ & $\begin{array}{l}\text { Direvisi: } \\
-\end{array}$ & $\begin{array}{l}\text { Distujui: } \\
\text { 2021-09-04 }\end{array}$ & $\begin{array}{l}\text { Dipublikasi: } \\
\text { 2021-10-29 }\end{array}$ \\
\hline \multicolumn{4}{|c|}{$\begin{aligned} \text { Pustaka : } & \text { Nurhabibah, P., Fikriyah, F., \& Dewi, K. (2021). PENGEMBANGAN WEBSITE } \\
& \text { EDUCANDY SEBAGAI ALAT EVALUASI PADA PEMBELAJARAN BAHASA } \\
& \text { INDONESIA UNTUK SISWA KELAS V. Fon: Jurnal Pendidikan Bahasa dan Sastra } \\
& \text { Indonesia, 17(2), 255-264. doi:https://doi.org/10.25134/fon.v17i2.4652 }\end{aligned}$} \\
\hline
\end{tabular}

\section{PENDAHULUAN}

Selama pandemi Covid-19 berlangsung, pemerintah menetapkan kebijakan BDR (Belajar Dari Rumah) untuk seluruh peserta didik baik di tingkat dasar, menengah, maupun perguruan tinggi. dalam situasi pandemi Covid-19 ini peserta didik lebih banyak memiliki waktu belajar di rumah karena sekolah masih mengikuti aturan pemerintah yang mengharuskan belajar di rumah secara daring dalam rangka pemutusan rantai 
penyebaran Covid- 19 (Fikriyah et al., 2020).

Bersekolah di rumah bagi keluarga Indonesia adalah sebuah tradisi baru khususnya bagi produktivitas orang tua yang biasanya sibuk dengan pekerjaannya di luar rumah. Selain itu siswa mengalami problem psikologis karena terbiasa belajar bertatap muka langsung dengan guru-guru mereka (Munajim et al., 2020)

Peran guru di era globalisasi menjadi sangat sentral terutama dalam memberikan penguatan nilai. Adanya pewaris nilai negatif melalui media dan publik figur turut mempengaruhi karakter siswa yang bertentangan dengan nilai luhur agama dan moralitas bangsa yang diajarkan di sekolah (Pratama et al., 2021).

Pada keadaan seperti ini pengajar diharuskan mampu membuat inovasi untuk manajemen kelas dalam rangka meningkatkan motivasi dan prestasi (Fitriati et al., 2021).

Selain itu, guru sebagai fasilitator haruslah mampu membuat media evaluasi yang tepat, media evaluasi ini sangat berpengaruh dalam peningkatan pemahaman dan prestasi belajar siswa (Agustinasari et al., 2020). Metode pembelajaran dengan memanfaatkan teknologi melalui dalam jaringan (daring), memiliki tantangan tersendiri di saat mewabahnya pandemi saat ini (Nurhabibah et al., 2020)

Permasalahan yang terjadi di SD Negeri 1 Gintung Kidul kususnya di kelas $\mathrm{V}$ adalah menurunnya motivasi dan hasil evaluasi belajar peserta didik ketika melakukan Pembelajaran Jarak Jauh (PJJ). Perangkat evaluasi yang kurang menarik juga menjadi salah satu penyebab menurunnya hasil evaluasi peserta didik karena peserta didik hanya melakukan pembelajaran dengan mengerjakan Bahan Ajar Jarak Jauh (BAJJ) yang disediakan oleh pihak sekolah. Bahkan tidak jarang orang tua peserta didiklah yang mengerjakan bahan ajar tersebut, sehingga peneliti berinisiatif membuat alat evaluasi yang bisa diakses menggunakan gawai yang berisi soal-soal evaluasi pembelajaran interaktif yang lebih menarik minat peserta didik menggunakan Educandy.

Educandy adalah aplikasi berbasis web yang memiliki slogan 'making learning sweeter' (membuat belajar lebih manis). Educandy dapat digunakan untuk membuat permainan daring yang menyenangkan (Fitriati et al., 2021). Dengan Educandy, kita dapat membuat game belajar interaktif dalam hitungan menit, educandy memiliki tampilan yang sangat mudah dimengerti bagi pengguna awam.

Ada delapan model game belajar yang bisa dibuat, diantaranya : Crosswords (teka teki silang), Multiple Choise (pilihan ganda), Word Search (mencari kata diantara susunan huruf acak), Noughts \& Crosses (memilih jawabanyang benar dengan hingga pada posisi melintang), spell It (menberikan jawaban dengan cara mengeja huruf demi huruf), Anagram (pertukaran huruf dalam kata-kata sehingga kata itu mempunyai arti lain), Match-up (menjodohkan), memory (memilih jawaban sesuai pada urutan yang ditentukan) (Fitriati et al., 2021).

Penelitian terdahulu mengenai pengembangan alat evaluasi educandy dilakukan di tingkat perguruan tinggi. Penelitian mengenai alat evaluasi berbasis educandy hanya ditemukan satu judul oleh Fitriati (2020) berjudul Implementasi Digital Game Based Learning Menggunakan Aplikasi Educandy Untuk Evaluasi Dan Motivasi Belajar Mahasiswa Bima. Penelitian Fitriati hanya sebatas membuat panduan penilaiannya saja tanpa divalidasi oleh beberapa ahli. Sehingga tingkat kelayakan dari alat evaluasi tersebut belum dapat dikatakan valid dan sesuai untuk peserta 
didik. Sehingga penulis merasa perlu untuk membuat penelitian mengenai alat evaluasi menggunakan website educandy yang sudah divalidasi oleh beberapa ahli yaitu ahli media pembelajaran dan ahli materi bahasa.

Bermula dari pemikiran di atas, penelitian ini dilakukan sebagai upaya untuk mengatasi penurunan hasil evaluasi belajar peserta didik dengan menggunakan aplikasi berbasis web yaitu educandy. Setelah diperoleh hasil validasi dari beberapa ahli media dan materi, aplikasi ini siap digunakan untuk mengerjakan beberapa soal latihan maupun ulangan sebagai alat evaluasi di SD agar peserta didik lebih bersemangat dan pembelajaran menjadi jauh lebih menyenangkan. Penelitian ini bertujuan untuk mendeskripsikan dan menjelaskan: (1) langkah-langkah pengembangan evaluasi pembelajaran interaktif berbasis Website Educandy, (2) kelayakan dari pengembangkan evaluasi pembelajaran interaktif berbasis Website Educandy.

\section{METODE}

Metode yang digunakan dalam penelitian ini adalah pengembangan atau biasa disebut dengan Research and Development $(R \& D)$. Menurut Sugiyono (2017: 297), Research and Development adalah metode penelitian yang digunakan untuk menghasilkan produk tertentu dan menguji keefektifan dari produk tersebut.

Dalam penelitian pengembangan ini peneliti berusaha mengembangkan produk berupa pengembangan evaluasi pembelajaran interaktif berbasis Website Educandy dengan menggunakan model pengembangan yang mengacu pada model pengembangan Thiagarajan. Model pengembangan Thiagarajan dikenal dengan model pengembangan 4D yang terdiri dari tahapan, yaitu tahap pendefinisian (define), perancangan (design), pengembangan (develop), dan diseminasi (disseminate) (Tim Dosen UMC, 2021: 46).

Dalam perancangan Website Educandy ini pendidik hanya perlu merangkum materi yang kemudian akan dibuat soal evaluasi dari hasil rangkuman materi tersebut. Setelah soal selesai dibuat, langah selanjutnya adalah mengunjungi situs Website Educandy melalui halaman website www.educandy.com yang kemudian dilanjutkan dengan mendaftar atau sign in menggunakan e-mail, baik menggunakan $e$-mail sekolah maupun $e$-mail pribadi pendidik. Setelah proses pendaftaran berhasil maka pendidik hanya perlu menginput soal yang telah dibuat sebelumnya ke dalam website. Namun sebelum proses input soal, pendidik harus menentukan terlebih dahulu jenis soal seperti apa yang akan dibuat untuk menyesuaikan dengan fitur yang tersedia di Website Educandy karena dalam Website Educandy terdapat 3 fitur utama seperti words yang dapat digunakan untuk belajar kosa kata, machting pairs, dan quiz questions tetapi di dalam fitur utama tersebut memiliki beberapa fitur pilihan jadi sebelum menginput soal ke dalam website maka sebaiknya pendidik sudah menentukan jenis soal seperti apa yang akan digunakan dalam evaluasi kali ini. Kemudian, apabila semua soal sudah di input ke website maka pendidik hanya perlu membagikan link yang berisi soalsoal evaluasi melalui Whatsapp Group kepada para peserta didik.

\section{HASIL DAN PEMBAHASAN}

Langkah-langkah pembuatan soal evaluasi menggunakan website educandy sebagai berikut:

a) Mengunjungi Halaman Website

Langkah pertama yang harus dilakukan adalah membuat soal evaluasi yang disesuaikan dengan materi yang ada 
di buku siswa. Kemudian langkah selanjutnya dapat dilakukan dengan mengunjungi situs Website Educandy dengan alamat www.educandy.com yang akan muncul pada tampilan halaman awal seperti berikut berikut ini yang dilengkapi dengan beberapa fitur alternatif pilihan soal yang dapat digunakan dalam membuat soal evaluasi melalui Website Educandy.

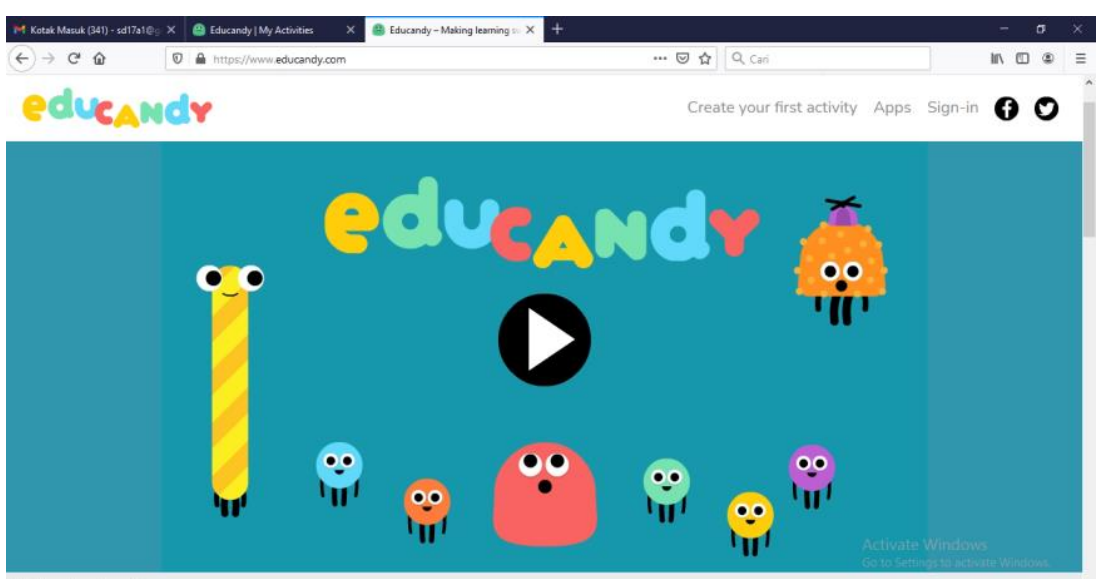

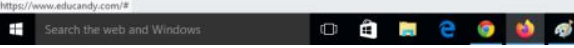

का 目
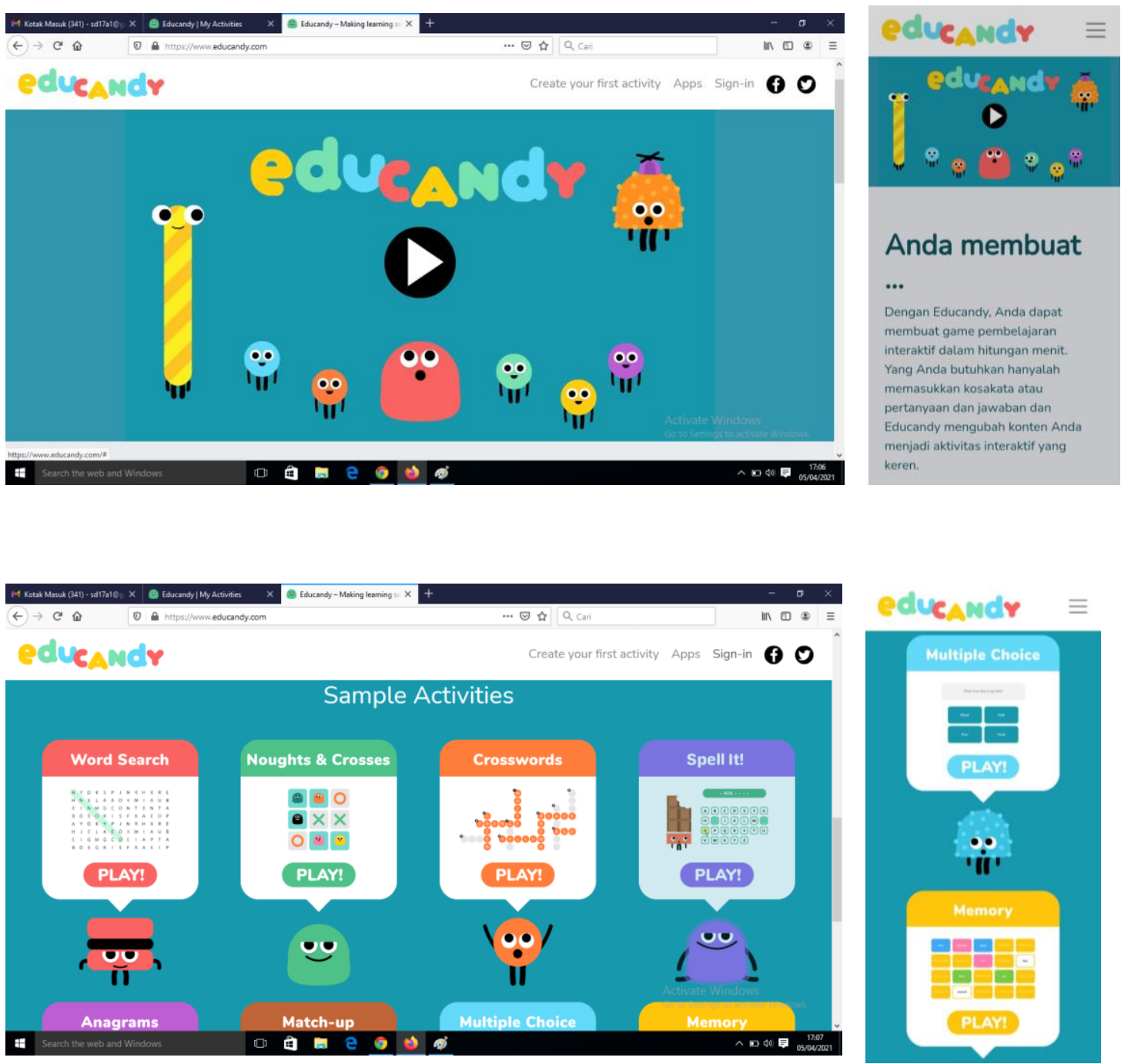

b) Sign In Website

Setelah berhasil mengunjungi halaman Website Educandy, maka langkah selanjutnya adalah sign in atau mendaftar dengan menggunakan alamat $e$ mail seperti berikut ini. 


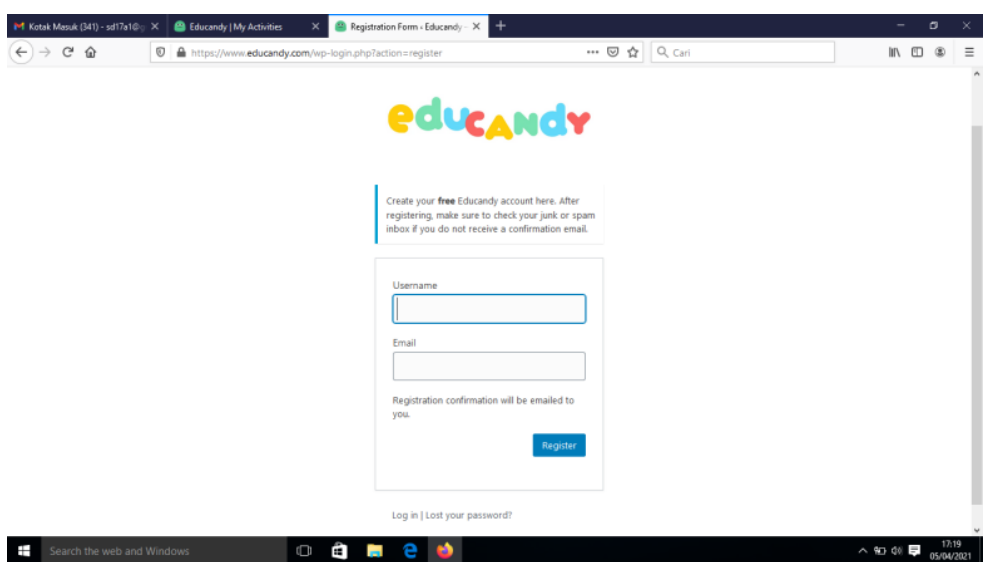

Setelah proses sign in atau $\mid$ My Activities, Import, Apps, logo pendaftaran berhasil maka akan muncul halaman utama Website Educandy yang di dalamnya terdiri dari fitur My Account,

Facebook dan Twitter, serta kolom Search seperti berikut ini

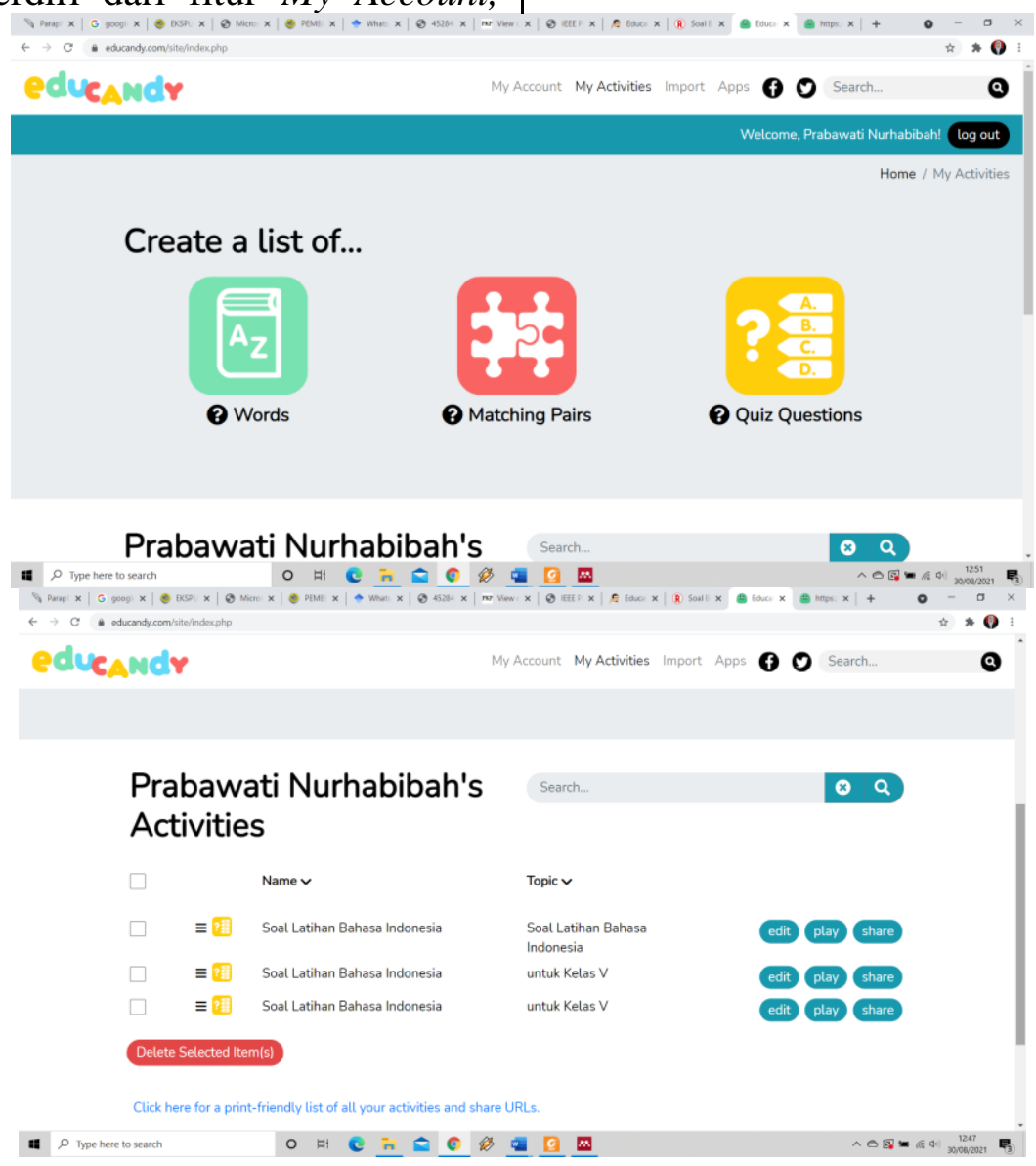

Input Soal

Setelah proses pendaftaran berhasil maka langkah selanjutnya adalah menginput soal ke dalam Website Educandy. Namun sebelum proses input soal, pendidik harus menentukan jenis soal seperti apa yang akan dibuat dan kemudian disesuaikan dengan fitur utama yang tersedia di Website Educandy. Website Educandy ini memiliki 3 fitur utama seperti words, machting pairs, dan quiz questions tetapi 
Program Studi Pendidikan Bahasa dan Sastra Indonesia

FKIP Universitas Kuningan

di dalam fitur utama juga memiliki | beberapa fitur pilihan.

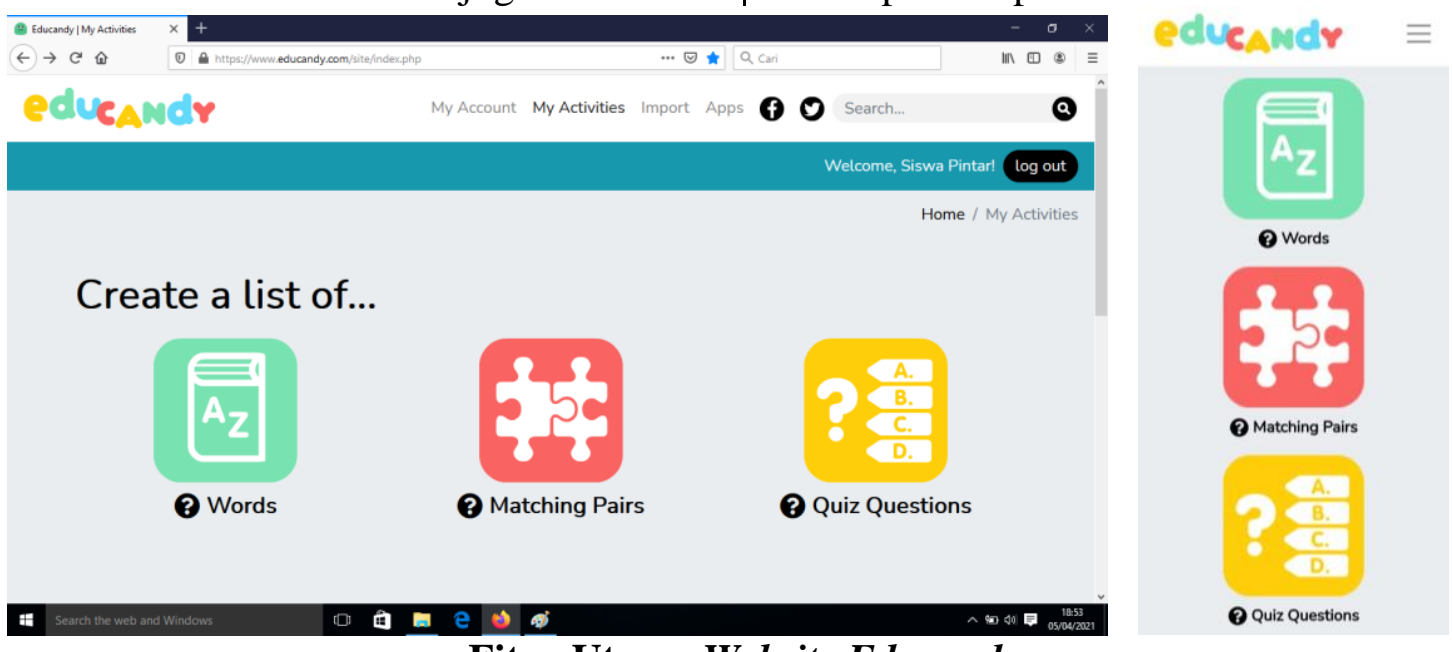

\section{Fitur Utama Website Educandy}

Dalam hal ini peneliti mencoba menginput soal dengan menggunakan fitur Quiz Questions. Berikut halaman soal Quiz Questions.

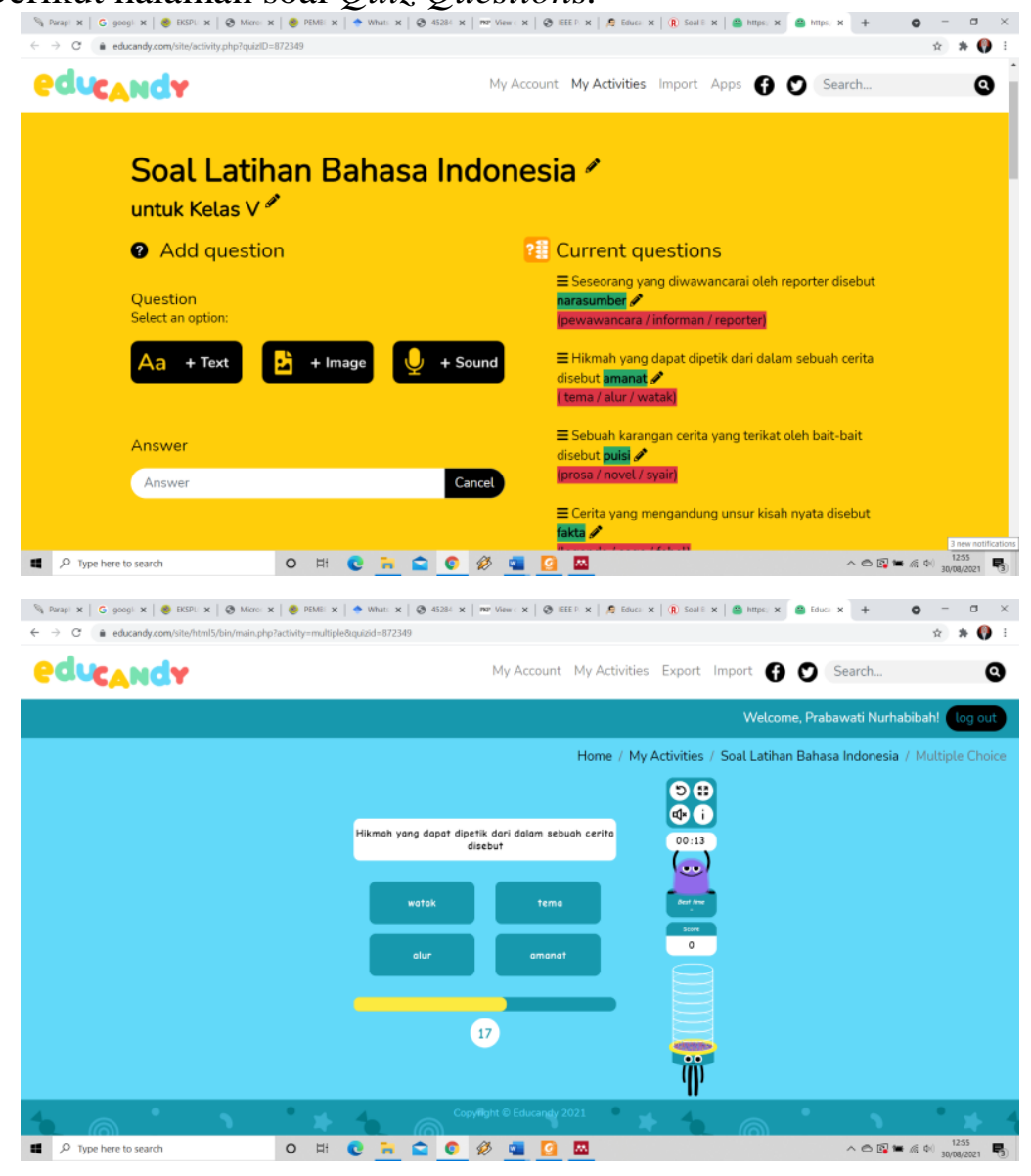

\section{Instruksi Pengerjaan Soal}

Dalam penelitian ini proses penginputan soal dalam website menggunakan fitur Quiz Question dan peroses menjawab soal-soalnya menggunakan Multiple Choice. Dalam

proses menjawab soal peserta didik diberikan waktu selama 30 detik untuk masing-masing soalnya, apabila peserta didik menjawab dengan tepat maka akan memperoleh skor sebanyak 20 poin karena masing-masing pertanyaannya 
memiliki skor 20 poin dan apabila jawaban soal kurang tepat poin yang diperoleh tidak berkurang tetapi jika waktu pengerjaannya belum mencapai 30 detik maka peserta didik masih bisa mencari jawaban yang tepat, namun apabila dalam waktu 30 detik peserta didik tidak dapat menjawab soal dengan tepat maka peserta didik dinyatakan salah dalam menjawab soal tersebut. Berikut gambar tampilan website yang diakses oleh peserta didik dalam menjawab soal evaluasi dengan menggunakan Multiple Choice.

Setelah semua soal selesai di kerjakan oleh peserta didik maka website akan menampilkan skor akhir atau total skor yang diperoleh peserta didik dari hasil menyelesaikan semua soal pada Website Educandy, kemudian peserta didik diminta untuk secreanshoot skor akhir yang kemudian dikirimkan ke grup Whatsapp seperti pada gambar di bawah ini.

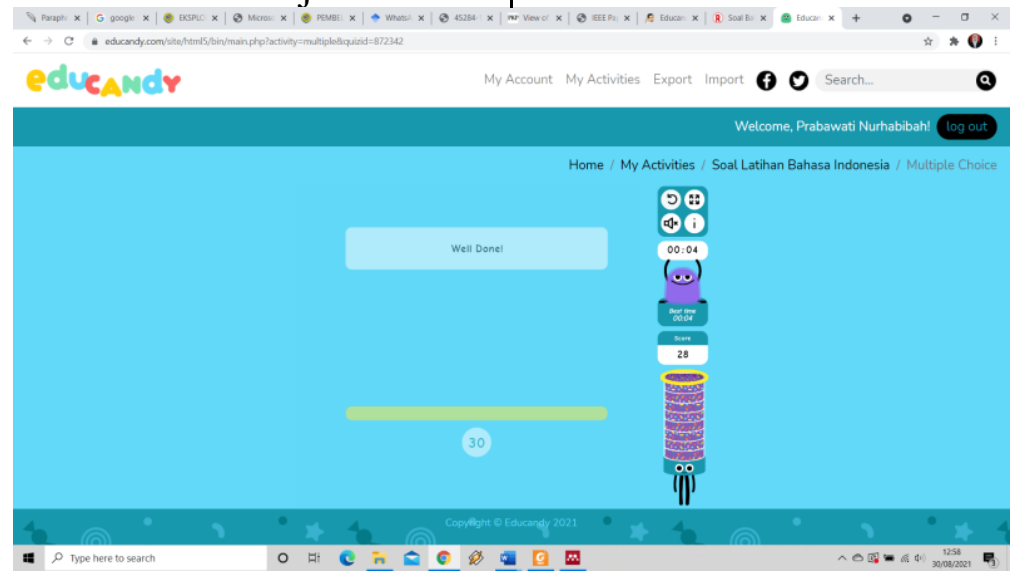

\section{Hasil Penilaian Media Evaluasi Pembelajaran Interaktif Berbasis Website Educandy oleh Ahli Media}

\begin{tabular}{|l|l|c|c|c|c|}
\hline \multicolumn{1}{|c|}{ Aspek } & \multicolumn{1}{|c|}{ Peryataan } & $\mathbf{X}$ & $\mathbf{X}_{\mathbf{1}}$ & $\mathbf{P}(\boldsymbol{\%})$ & $\begin{array}{c}\text { Tingkat } \\
\text { Kevalidan }\end{array}$ \\
\hline \multirow{4}{*}{ Konsep media } & Pernyataan 1 & 4 & 5 & $80 \%$ & Layak \\
\cline { 2 - 6 } & Pernyataan 2 & 3 & 5 & $60 \%$ & Cukup Layak \\
\cline { 2 - 6 } & Pernyataan 3 & 4 & 5 & $80 \%$ & Layak \\
\cline { 2 - 6 } & Pernyataan 4 & 4 & 5 & $80 \%$ & Layak \\
\cline { 2 - 6 } & Pernyataan 5 & 4 & 5 & $80 \%$ & Layak \\
\hline Tampilan/desain & Pernyataan 6 & 5 & 5 & $100 \%$ & Sangat Layak \\
\cline { 2 - 6 } & Pernyataan 7 & 5 & 5 & $100 \%$ & Sangat Layak \\
\cline { 2 - 6 } & Pernyataan 8 & 5 & 5 & $100 \%$ & Sangat Layak \\
\cline { 2 - 6 } & Pernyataan 9 & 5 & 5 & $100 \%$ & Sangat Layak \\
\cline { 2 - 6 } & Pernyataan 10 & 5 & 5 & $100 \%$ & Sangat Layak \\
\hline \multirow{5}{*}{ Efektivitas } & Pernyataan 11 & 4 & 5 & $80 \%$ & Layak \\
\cline { 2 - 6 } & Pernyataan 12 & 4 & 5 & $80 \%$ & Layak \\
\cline { 2 - 6 } & Pernyataan 13 & 4 & 5 & $80 \%$ & Layak \\
\cline { 2 - 6 } & Pernyataan14 & 5 & 5 & $100 \%$ & Sangat Layak \\
\cline { 2 - 6 } & Pernyataan 15 & 4 & 5 & $80 \%$ & Layak \\
\hline \multirow{6}{*}{ Jumlah } & $\mathbf{6 5}$ & $\mathbf{7 5}$ & $\mathbf{8 6 , 6 7} \%$ & Sangat Layak \\
\hline
\end{tabular}


Data yang tertera di atas hasil proses dari perhitungan dengan menggunakan rumus berikut:

$$
\mathrm{P}=\frac{\sum x i}{\sum x} \times 100 \%
$$

Keterangan:

$\mathrm{P} \quad=$ Persentase kelayakan

$\sum \mathrm{xi}=$ Jumlah total skor yang diperoleh dari validator.

$\sum \mathrm{x}=$ Jumlah skor ideal

$100 \%=$ Bilangan konstan

Jika dihitung

$\mathrm{P}=$

$4+3+4+4+4+5+5+5+5+5+4+4+4+5+4$ $5 \times 15$

\section{Hasil Penilaian Materi Evaluasi Pembelajaran Interaktif Berbasis Website Educandy oleh Ahli Materi I}

\begin{tabular}{|c|c|c|c|c|c|}
\hline Aspek & Peryataan & $\mathbf{X}$ & $\mathbf{X}_{1}$ & $\mathbf{P}(\%)$ & $\begin{array}{c}\text { Tingkat } \\
\text { Kevalidan } \\
\end{array}$ \\
\hline \multirow[t]{5}{*}{ Kesesuaian soal } & Pernyataan 1 & 5 & 5 & $100 \%$ & Sangat Layak \\
\hline & Pernyataan 2 & 5 & 5 & $100 \%$ & Sangat Layak \\
\hline & Pernyataan 3 & 4 & 5 & $80 \%$ & Layak \\
\hline & Pernyataan 4 & 5 & 5 & $100 \%$ & Sangat Layak \\
\hline & Pernyataan 5 & 4 & 5 & $80 \%$ & Layak \\
\hline \multirow[t]{5}{*}{ Kualitas soal } & Pernyataan 6 & 5 & 5 & $100 \%$ & Sangat Layak \\
\hline & Pernyataan 7 & 4 & 5 & $80 \%$ & Layak \\
\hline & Pernyataan 8 & 5 & 5 & $100 \%$ & Sangat Layak \\
\hline & Pernyataan 9 & 4 & 5 & $80 \%$ & Layak \\
\hline & Pernyataan 10 & 5 & 5 & $100 \%$ & Sangat Layak \\
\hline \multirow[t]{5}{*}{ Efektivitas soal } & Pernyataan 11 & 5 & 5 & $100 \%$ & Sangat Layak \\
\hline & Pernyataan 12 & 5 & 5 & $100 \%$ & Sangat Layak \\
\hline & Pernyataan 13 & 4 & 5 & $80 \%$ & Layak \\
\hline & Pernyataan14 & 5 & 5 & $100 \%$ & Sangat Layak \\
\hline & Pernyataan 15 & 5 & 5 & $100 \%$ & Sangat Layak \\
\hline \multicolumn{2}{|c|}{ Jumlah } & 70 & 75 & $93,33 \%$ & Sangat Layak \\
\hline \multicolumn{3}{|c|}{$\begin{array}{l}\text { Data yang tertera di atas hasil proses } \\
\text { dari perhitungan dengan menggunakan } \\
\text { rumus berikut: }\end{array}$} & $\begin{array}{l}\sum \mathrm{x} \\
100 \% \\
\text { Jika c } \\
\mathrm{P} \\
5+5+4\end{array}$ & $\begin{array}{l}=\text { Jumlah } \\
=\text { Bilanga } \\
\text { hitung } \\
= \\
-5+4+5+4+\end{array}$ & $\begin{array}{l}\text { Oor ideal } \\
\text { konstan }\end{array}$ \\
\hline \multicolumn{3}{|c|}{$\begin{array}{l}\mathrm{P} \quad=\text { Persentase kelayakan } \\
\sum \mathrm{xi}=\text { Jumlah total skor yang diperoleh } \\
\text { dari validator. }\end{array}$} & & & \\
\hline
\end{tabular}


Program Studi Pendidikan Bahasa dan Sastra Indonesia

FKIP Universitas Kuningan

$=\frac{70}{75} \times 100 \%$

$=93,33 \%$

Dari hasil validasi materi di atas dapat dikatakan bahwa materi evaluasi pembelajaran interaktif berbasis Website Educandy yang telah dikembangkan ini memiliki tingkat kevalidan sebesar

\section{Hasil Penilaian Materi Evaluasi Pembelajaran Interaktif Berbasis Website Educandy oleh Ahli Materi II}

\begin{tabular}{|c|c|c|c|c|c|}
\hline Aspek & Peryataan & $\mathbf{X}$ & $\mathbf{X}_{1}$ & $\mathbf{P}(\%)$ & $\begin{array}{c}\text { Tingkat } \\
\text { Kevalidan }\end{array}$ \\
\hline \multirow[t]{5}{*}{ Kesesuaian soal } & Pernyataan 1 & 4 & 5 & $80 \%$ & Layak \\
\hline & Pernyataan 2 & 5 & 5 & $100 \%$ & Sangat Layak \\
\hline & Pernyataan 3 & 5 & 5 & $100 \%$ & Sangat Layak \\
\hline & Pernyataan 4 & 5 & 5 & $100 \%$ & Sangat Layak \\
\hline & Pernyataan 5 & 4 & 5 & $80 \%$ & Layak \\
\hline \multirow[t]{5}{*}{ Kualitas soal } & Pernyataan 6 & 4 & 5 & $80 \%$ & Layak \\
\hline & Pernyataan 7 & 5 & 5 & $100 \%$ & Sangat Layak \\
\hline & Pernyataan 8 & 5 & 5 & $100 \%$ & Sangat Layak \\
\hline & Pernyataan 9 & 5 & 5 & $100 \%$ & Sangat Layak \\
\hline & Pernyataan 10 & 5 & 5 & $100 \%$ & Sangat Layak \\
\hline \multirow[t]{5}{*}{ Efektivitas soal } & Pernyataan 11 & 5 & 5 & $100 \%$ & Sangat Layak \\
\hline & Pernyataan 12 & 5 & 5 & $100 \%$ & Sangat Layak \\
\hline & Pernyataan 13 & 4 & 5 & $80 \%$ & Layak \\
\hline & Pernyataan14 & 5 & 5 & $100 \%$ & Sangat Layak \\
\hline & Pernyataan 15 & 4 & 5 & $80 \%$ & Layak \\
\hline \multicolumn{2}{|c|}{ Jumlah } & 70 & 75 & 93,33\% & Sangat Layak \\
\hline \multicolumn{3}{|c|}{$\begin{array}{l}\text { Data yang tertera di atas hasil proses } \\
\text { dari perhitungan dengan menggunakan } \\
\text { rumus berikut: }\end{array}$} & \multicolumn{3}{|c|}{$=\frac{70}{75} \times 100 \%$} \\
\hline
\end{tabular}

$$
\mathrm{P}=\frac{\sum x i}{\sum x} x 100 \%
$$

Keterangan:

$\mathrm{P} \quad=$ Persentase kelayakan

$\sum \mathrm{xi}=$ Jumlah total skor yang diperoleh

dari validator.

$\sum \mathrm{x}=$ Jumlah skor ideal

$100 \%=$ Bilangan konstan

Jika dihitung

$\mathrm{P}=$

$\frac{5+5+4+5+4+5+4+5+4+5+5+5+4+5+5}{5 \times 15} \times 100 \%$
93,33\% hal ini di buktikan dengan jumlah skor pada item pernyataan $1-15$ yang terdapat pada angket yang di isi oleh validator terhadap materi evaluasi pembelajaran interaktif berbasis Website Educandy yaitu sebesar 70 poin dengan presentase kevalidan sebesar 93,33\% yang termasuk ke dalam kriteria sangat layak.
Dari hasil validasi materi di atas dapat dikatakan bahwa materi evaluasi pembelajaran interaktif berbasis Website Educandy yang telah dikembangkan ini memiliki tingkat kevalidan sebesar 93,33\% hal ini di buktikan dengan jumlah skor pada item pernyataan $1-15$ yang terdapat pada angket yang di isi oleh validator terhadap materi evaluasi pembelajaran interaktif berbasis Website Educandy yaitu sebesar 70 poin dengan presentase kevalidan sebesar 93,33\% yang termasuk ke dalam kriteria sangat layak. 


\section{KESIMPULAN}

Hasil validasi dari pengembangan evaluasi pembelajaran interaktif berbasis Website Educandy memiliki tingkat kevalidan yang tinggi sehingga layak digunakan dalam proses evaluasi pembelajaran. Berdasarkan hasil tanggapan kritik dan saran serta penilaian dari para validator mendapatkan kategori "Sangat Valid". Penilaian dari validator ahli media yang diperoleh persentase kelayakan mencapai $86,67 \%$ dengan kategori "Sangat Valid". Penilaian dari validator ahli materi diperoleh persentase kelayakan mencapai 93,33\% dengan kategori "Sangat Valid". Penilaian dari validator ahli materi diperoleh persentase kelayakan mencapai 93,33\% dengan kategori "Sangat Valid".

\section{DAFTAR PUSTAKA}

Agustinasari, Susilawati, E., \& Fitriati, I. (2020). Peningkatan Kemampuan Guru SMAN 2 Woha Dalam Melakukan Evaluasi Pembelajaran Menggunakan CBT. JMM: Jurnal Masyarakat Mandiri, 4(2), 273-280.

Fikriyah, F., Rohaeti, T., \& Solihati, A. (2020). Peran Orang Tua dalam Meningkatkan Literasi Membaca Peserta Didik Sekolah Dasar. DWIJA CENDEKIA: Jurnal Riset Pedagogik, 4(1), https://doi.org/10.20961/jdc.v4i1.439
37

Fitriati, I., Purnamasari, R., Fitrianingsih, N., \& Irawati, I. (2021). Implementasi Digital Game Based Learning Menggunakan Aplikasi Educandy Untuk Evaluasi Dan Motivasi Belajar Mahasiswa Bima. Prosiding Penelitian Dan Pengabdian 2021, 307-312. http://prosiding.rcipublisher.org/inde x.php/prosiding/article/view/152

Munajim, A., Barnawi, B., \& Fikriyah, F. (2020). Pengembangan Kurikulum Pembelajaran di Masa Darurat. DWIJA CENDEKIA: Jurnal Riset Pedagogik, $\quad 4(2), \quad 285$. https://doi.org/10.20961/jdc.v4i2.452 88

Nurhabibah, P., Hanikah, H., \& Widiawati, H. (2020). Aplikasi Pilihan Pendukung Pembelajaran Daring pada Mahasiswa Pendidikan Guru Sekolah Dasar. DWIJA CENDEKIA: Jurnal Riset Pedagogik, 4(2), 257. https://doi.org/10.20961/jdc.v4i2.452 84

Pratama, R. B., Fikriyah, \& Titi, R. (2021). Pengembangan E-Modul Bemuatan Kearifan Lokal Pada Pembelajaran Tematik Di Kelas V SDN 2 Waruroyom. Jurnal Kependidikan Dasar, 11(2), 16. 